\title{
GABA ( $\gamma$-aminobutyric acid) production, antioxidant activity in some germinated dietary seeds and the effect of cooking on their GABA content
}

\author{
Kasarin TIANSAWANG ${ }^{1,2}$, Pairoj LUANGPITUKSA ${ }^{1}$, Warunee VARANYANOND², Chanida HANSAWASDI ${ }^{4 *}$
}

\begin{abstract}
Germinated grains have been known as sources of Gamma-aminobutyric acid (GABA) that provide beneficial effects for human health. This study was aimed to investigate GABA production, dietary fiber, antioxidant activity, and the effect of cooking on GABA loss in germinated legumes and sesame. The highest GABA content was found in germinated mung bean, $\left(0.8068 \mathrm{~g} \mathrm{~kg}^{-1}\right.$, $24 \mathrm{~h}$ incubation) followed by germinated soybean, germinated black bean and soaked sesame. Beside GABA, dietary fiber content also increased in all grains during germination where the insoluble dietary fiber fractions were always found in higher proportions to soluble dietary fiber fractions. Our results also confirmed that germinated mung bean is a rich source of GABA and dietary fibers. Microwave cooking resulted in the smallest loss of GABA in mung bean and sesame, while steaming led to the least GABA content loss in soybean and black bean. Therefore microwave cooking and steaming are the most recommended cooking processes to preserve GABA in germinated legumes and sesame.
\end{abstract}

Keywords: gamma-aminobutyric acid; legume; sesame; cooking effect.

Practical Application: Germinated mung bean can potentially be used to enrich foods with GABA and dietary fibers.

\section{Introduction}

Gamma-aminobutyric acid (GABA) is a four carbon amino acid that is produced by the decarboxylation of L-glutamic acid that catalyzed by glutamate decarboxylase enzyme (Komatsuzaki et al., 2007). GABA is an inhibitory neurotransmitter in the sympathetic nervous system (Wang et al., 2006) and is widely distributed in nature. GABA provides many beneficial effects for human health such as decreasing blood pressure, controlling stress (Chung et al., 2009), diuretic effect, tranquilizer effect, while germinated brown rice with enhanced levels of GABA can inhibit cancer cell proliferation (Oh \& Oh, 2004). Many kinds of food such as germinated grains have high content of GABA. During germination process, the biochemical activities of germinated grains produce essential compounds for the formation of the seedling. Accordingly, these processes lead to increasing amounts of simple sugars, peptides and amino acids in germinated seeds, such as in wheat (Moongngarm \& Saetung, 2010), barley (Chung et al., 2009), and rice (Saman et al., 2008). In addition, many enzymes are activated, which may produce minor nutrients such as GABA and vitamins. Germinated cereal grains have been widely studied for GABA production such as in germinated barley (Chung et al., 2009), germinated rice (Komatsuzaki et al., 2007; Zhang et al., 2007; Thuwapanichayanan et al., 2015; Kim et al., 2015) and soybean (Xu \& Hu, 2014).

Legumes and sesame seed are highly nutritious food ingredients. Mung bean is an excellent source of protein, rich in vitamins, especially thiamin, riboflavin and niacin, and minerals. Soybean proteins are considered high quality proteins, rich in lysine, and their amino acid profile resemble that of cereal proteins (Castrorubio et al., 2006). It was reported that GABA levels in soybean sprouts were rapidly increased during the early stage of germination (Matsuyama et al., 2009). Black bean is also a rich source of proteins, fibers, several vitamins and essential minerals such as calcium and iron (Girish et al., 2012). Sesame seeds contain many compounds that have antioxidant activity such as sesamin, sesamolin, sesamol, and sesaminol (Hahma et al., 2009; Rangkadilok et al., 2010). On the other hand, legumes and sesame have been reported to possess antinutritional factors such as trypsin inhibitor, phytic acid, and tannins (Siddhuraju et al., 2002). Cooking is usually useful to inactivate heat-labile antinutritional factors. However, cooking processes cause considerable losses in vitamins and minerals (Alajaji and El-Adawy, 2006; Mubarak, 2005). A previous study reported that germination process enhances the nutritive value of legumes by reducing the antinutritional and indigestible factors in legumes (Bau et al., 1997). However, only a few studies have reported the accumulation of GABA and nutritional composition during germination (Matsuyama et al., 2009; Oh \& Choi, 2001; Martínez-Villaluenga et al., 2006; Shen et al., 2015) and the effect of cooking process on GABA loss in germinated legumes and sesame (Sirisoontaralak et al., 2015).

Therefore, the aim of this research was to study the appropriate germination condition of grains, which were mung bean (Vigna radiata), soybean (Glycine max), black bean (Vigna mungo), and sesame (Sesamum indicum) in producing 
GABA. Also, physicochemical composition, dietary fiber content and antioxidant activity of germinated legumes and sesame were investigated. Additionally, the effect of domestic traditional cooking such as boiling, steaming, microwave cooking and open pan roasting on the GABA content of germinated grains was evaluated.

\section{Materials and methods}

\subsection{Grains samples}

The grains used in this study were mung bean (Vigna radiata), soybean (Glycine max), black bean (Vigna mungo), and sesame (Sesamum indicum). They were obtained from Institute of Food Research and Product Development, Kasetsart University, Bangkok, Thailand.

\subsection{Germination condition}

Grain samples were soaked in distilled water (1:5, w/v) for $6 \mathrm{~h}$ at room temperature. Samples were then incubated in plastic container and placed between of moist cloth layers at room temperature. As germination progressed germinated grains were randomly selected for analysis at different incubation times, which were 0 (immediately after soaking), 6, 12, 24, 36 and $48 \mathrm{~h}$. The sample grains were then dried in hot air oven at $50{ }^{\circ} \mathrm{C}$ for $8 \mathrm{~h}$ and subjected to further analysis for GABA content, proximal food composition, dietary fiber content and antioxidant activity.

\subsection{GABA content analysis}

The GABA content measurement was carried out by the modified method of Srisang et al. (2011). The germinated grains were finely ground and extracted with $3 \%$ sulfosalicylic acid $(0.5 \mathrm{~g} / 200 \mathrm{~mL})$ for $1.5 \mathrm{~h}$ at room temperature. The extracts were centrifuged at $5,000 \times g$ for $10 \mathrm{~min}$ and the supernatant was collected and run through derivatization process. $50 \mu \mathrm{L}$ supernatant was mixed with $50 \mu \mathrm{L} \mathrm{NaHCO}$ and $200 \mu \mathrm{L}$ dimethylaminoazobenzene and incubated at $70{ }^{\circ} \mathrm{C}$ for $10 \mathrm{~min} .250 \mu \mathrm{L}$ ethanol and $250 \mu \mathrm{L}$ $\mathrm{KH}_{2} \mathrm{PO}_{4}$ were added and the solution was filtered through $0.45 \mu \mathrm{m}$ pore-size nylon filters. The derivative solution was analyzed by HPLC (Agilent 1100 Series, Agilent Technologies, California, USA) equipped with Supelcosil-LC-DABS column, where the detector was set at $465 \mathrm{~nm}$. Acetonitrile was used as a mobile phase with a flow rate $1 \mathrm{~mL} / \mathrm{min}$. The column temperature was controlled at $35^{\circ} \mathrm{C}$.

\subsection{Proximate analysis of food components}

The Kjeldahl method was used for the analysis of total nitrogen content, which then was utilized to calculate the protein content $(\mathrm{N} \times 6.25)$ (Association of Official Analytical Chemists, 1990b). Determination of total fat content was performed by gravimetric solvent extraction using Soxhlet extraction system and petroleum ether as extraction solvent (Association of Official Analytical Chemists, 2000). Ash was determined by combustion of the sample in a muffle furnace at $550{ }^{\circ} \mathrm{C}$ (Association of Official Analytical Chemists, 1990a) and total carbohydrate content was calculated by subtracting $\%$ protein, $\%$ ash, and $\%$ fat contents from total dry weight (100\%). All proximal values were reported as the average value of three replications.

\subsection{Dietary fiber content Determination}

The contents of total (TDF), soluble (SDF) and insoluble dietary fiber (IDF) were determined by the enzymatic-gravimetric method modified from AACC methods 32-05 and 32-21 using Total Dietary Fiber Assay Kit (Megazyme). The defatted sample was gelatinized with $50 \mu \mathrm{L}$ heat stable $\alpha$-amylase in $50 \mathrm{~mL}$ phosphate buffer $\left(0.08 \mathrm{~mol} \mathrm{~L}^{-1}, \mathrm{pH} 6.0\right)$. The sample was further digested with $100 \mu \mathrm{L}$ protease and $200 \mu \mathrm{L}$ amyloglucosidase. Thereafter, the solution was filtered; the residue was washed, dried and weighed to determine insoluble dietary fiber content. The filtrate was precipitated by adding four times volume of $60^{\circ} \mathrm{C} 95 \%$ ethanol. Then, the precipitates were filtered, washed, dried and weighed to determine soluble dietary fiber content. Determination of ashes and proteins in residues was carried out for corresponding corrections. Kjeldahl nitrogen and ash contents were assayed according to standard procedures (Association of Official Analytical Chemists, 1990b). The total dietary fiber content was calculated as the sum of insoluble dietary fiber and soluble dietary fiber contents.

\subsection{DPPH radical scavenging assay}

The extracts used for determination of 2,2-Diphenyl-1picrylhydrazyl (DPPH) radical scavenging and total phenolics content was prepared by refluxing the germinated grains powder with distilled water $(10 \mathrm{~g} / 100 \mathrm{~mL})$. The refluxed material was filtered and the supernatant was collected for analysis. The free-radical scavenging capacity of each extract was evaluated according to the procedure of Butsat \& Siriamornpun (2010) with some modifications. Briefly, $100 \mu \mathrm{L}$ of the extract was added to freshly prepared $0.1 \mathrm{mM}$ DPPH solution $(1.9 \mathrm{~mL})$, and the mixture was kept at room temperature in dark environment for $30 \mathrm{~min}$. The absorbance was measured at $517 \mathrm{~nm}$ and the antioxidant activity was calculated by the following Equation 1:

DPPH scavenging activity $(\%)=\left[\left(\mathrm{A}_{517 \text { control }}-\mathrm{A}_{517 \text { extract }}\right) \times 100\right] / \mathrm{A}_{517 \text { control }}$

\subsection{Total phenolics assay}

The total phenolics content was determined by the Folin-Ciocalteu method modified by Randhir \& Shetty (2007). Briefly, $1 \mathrm{~mL}$ of the sample extract was transferred into a test tube and mixed with $1 \mathrm{~mL}$ of $95 \%$ ethanol and $5 \mathrm{~mL}$ of distilled water. Folin-Ciocalteu reagent was added to each sample to a final concentration of $50 \%(\mathrm{v} / \mathrm{v})$ and mixed. After $5 \mathrm{~min}, 1 \mathrm{~mL}$ of $5 \% \mathrm{Na}_{2} \mathrm{CO}_{3}$ was added and the reaction mixture was allowed to stand for $60 \mathrm{~min}$. The absorbance was measured at $725 \mathrm{~nm}$. The standard curve was established using various concentrations of gallic acid in $95 \%$ methanol, and the result was expressed as $\mathrm{mg}$ of gallic acid equivalent per gram of dry weight sample (dry weight).

\subsection{The effect of cooking process on GABA content}

The germinated grains were soaked in distilled water $(1: 5, \mathrm{w} / \mathrm{v})$ for $3 \mathrm{~h}$ at room temperature to soften the grains. Then, they were rinsed twice with distilled water, and cooked by the methods described below: 
a. Boiling: Soaked grains were boiled in distilled water $\left(98-100^{\circ} \mathrm{C}\right)$ in the ratio of $1: 10(\mathrm{w} / \mathrm{v})$. Grains were cooked for $20 \mathrm{~min}$ and then rinsed again with distilled water.

b. Steaming: Soaked grains were cooked in steaming pot for $40 \mathrm{~min}$.

c. Microwave cooking: Soaked grains were placed in a plastic box with distilled water $(1: 5, \mathrm{w} / \mathrm{v})$ and then cooked in a microwave oven (Sharp R276) with $2450 \mathrm{MHz}, 800 \mathrm{~W}$ (IEC 60705) for $10 \mathrm{~min}$.

d. Open pan roasting: Non soaked germinated grains were roasted in open pan $\left(90-95^{\circ} \mathrm{C}\right)$. The grains of mung bean, soybean, and black bean were roasted for $10 \mathrm{~min}$, while germinated sesame was roasted for $5 \mathrm{~min}$.

Cooking treatments were replicated three times. After the germinated grains were subjected to the cooking process, they were analyzed for their GABA content and compared to uncooked germinated grains.
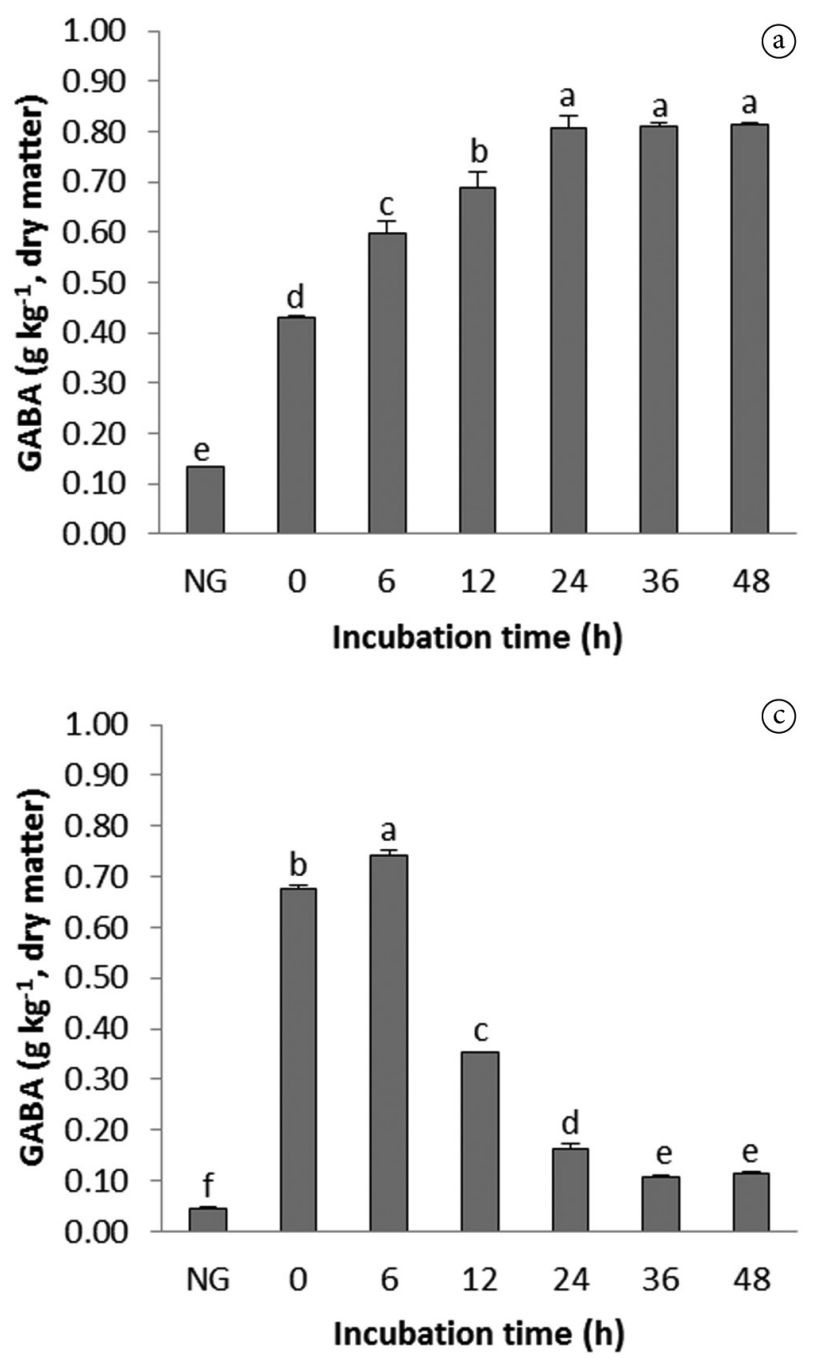

\subsection{Statistical analysis}

All analyses were performed in triplicate. Statistical analyses were carried out with Duncan's multiple test $(p<0.05)$ using statistical software SPSS V. 17 (SPSS Institute Inc., Cary, NC).

\section{Results and discussion}

\subsection{GABA content in germinated legumes and sesame}

After soaking and incubation, GABA content in germinated grains was generally higher than in non germinated grains (Figure 1). This indicated that the storage protein in grains was decomposed at least partially and supplied to the growing part of the seedlings and within this process glutamate decarboxylase enzyme was activated which converted glutamic acid to GABA. This result agrees with a previous report which found that the GABA contents in five cultivars of brown rice (Oryza sativa L. ssp. Japonica: Haiminori, Oou 359, Koshihikari, Yumetsukushi and Nipponbare) were significantly increased during soaking
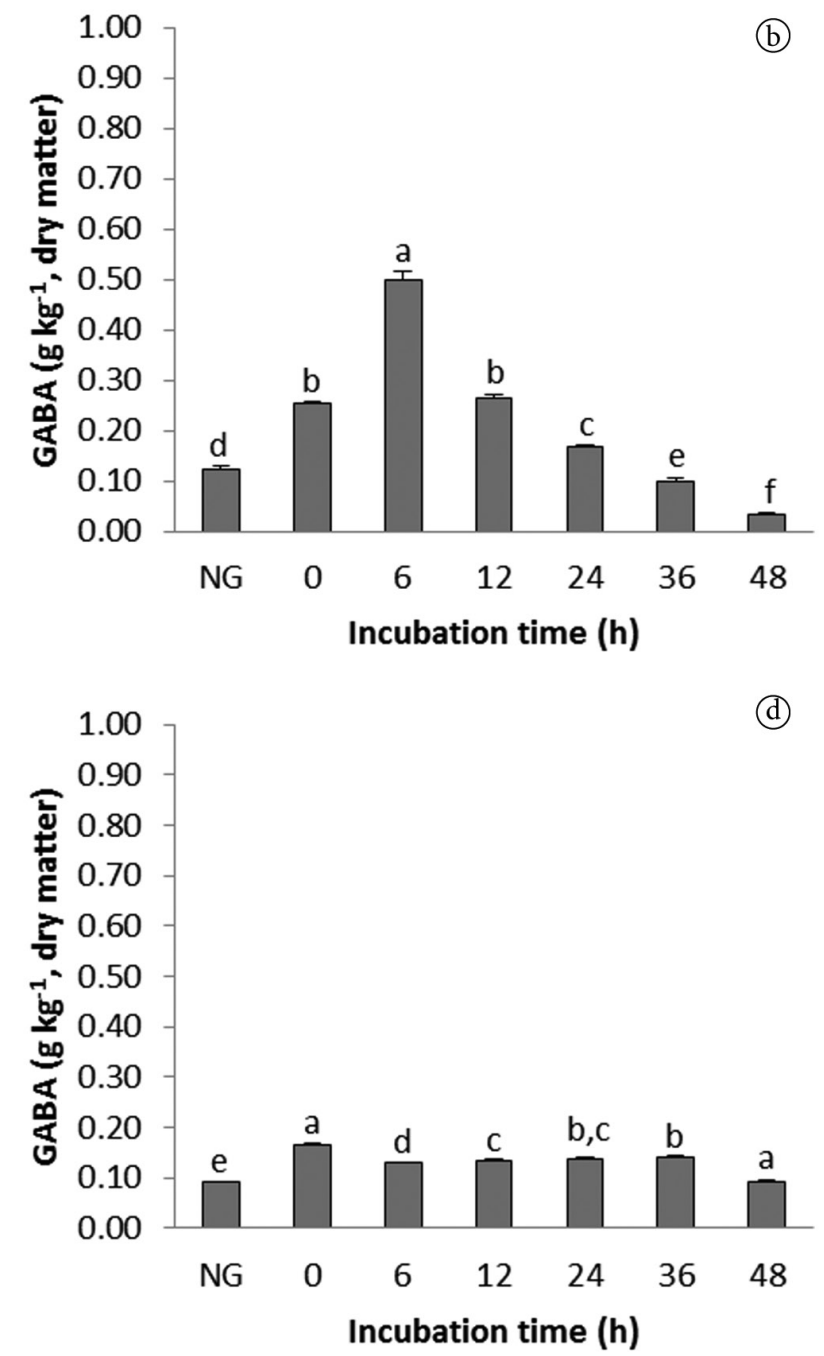

Figure 1. GABA contents of germinated grains at different incubation periods. NG denotes non germinated grains. (a) GABA content in germinated mung bean. (b) GABA content in germinated soybean. (c) GABA content in germinated black bean. And (d) GABA content in germinated sesame. Data reported are the mean \pm SD of triplicate determinations. ${ }^{\text {a-e }}$ Means of each grain type with different letters are significantly different $(p<0.05)$. 
and germination (Komatsuzaki et al., 2007). Similarly, GABA content in germinated barley and soy bean were found higher than in non germinated grains as reported by Chung et al. (2009) that in germinated barley steeping was found to contribute to the increasing of GABA content. Wang et al. (2015) also found that GABA content of Chinese soybean cultivar ZH 13 was increased 36.7-fold in day 5 of germination comparing to non germinated soybean.

The concentrations of GABA were $0.1325,0.1222,0.0438$ and $0.0907 \mathrm{~g} \mathrm{~kg}^{-1}$ dry matter in non germinated mung bean, soybean, black bean and sesame, respectively. After germination, the amount of GABA significantly increased especially in mung bean. GABA content in germinated mung bean increased up to $0.8068 \mathrm{~g} \mathrm{~kg}^{-1} \mathrm{dry}$ matter at $24 \mathrm{~h}$ of incubation period, however there was no further increase after $24 \mathrm{~h}$ (Figure 1a). The concentration of GABA in germinated soybean exponentially increased up to $0.4977 \mathrm{~g} \mathrm{~kg}^{-1}$ dry matter at $6 \mathrm{~h}$ of incubation period then decreased to 0.2638 and $0.1659 \mathrm{~g} \mathrm{~kg}^{-1}$ dry matter at $12 \mathrm{~h}$ and $24 \mathrm{~h}$, respectively (Figure $1 \mathrm{~b}$ ). After $6 \mathrm{~h}$ soaking ( $0 \mathrm{~h}$ incubation), the GABA content in germinated black bean was found to be $0.6773 \mathrm{~g} \mathrm{~kg}^{-1}$ dry matter and increased up to $0.7430 \mathrm{~g} \mathrm{~kg}^{-1}$ dry matter at $6 \mathrm{~h}$ of incubation period (Figure 1c). After that the GABA content decreased to 0.3526 and $0.1645 \mathrm{~g} \mathrm{~kg}^{-1}$ dry matter at $12 \mathrm{~h}$ and $24 \mathrm{~h}$, respectively. In sesame seeds, $6 \mathrm{~h}$ soaking alone increased the GABA content up to $0.1649 \mathrm{~g} \mathrm{~kg}^{-1}$ dry matter (Figure 1d). However it slightly decreased afterwards. Soaking leads to water absorption which activate the germination processes including glutamate decarboxylase enzyme that convert glutamic acid to GABA (Komatsuzaki et al., 2007). Rapid accumulation of GABA in early stage of soaking and germination of soybean and black bean has been suggested to be a probable response to water stress by young tissues (Matsuyama et al., 2009). Based on our results, the optimal incubation period for GABA production in germinated soybean and black bean was $6 \mathrm{~h}$. Interestingly, the highest GABA content in sesame was obtained after only soaking for $6 \mathrm{~h}$ without incubation period. However, it is difficult to compare the actual GABA content found in grains with difference in plant varieties and germination conditions. As in the study of Zhang et al. (2014) found that GABA production in indica and japonica germinated brown rice were different and influenced by genotypes and condition of soaking and germination. Our study supports the fact that soaking and germination were efficient processes to increase the levels of GABA in legumes and sesame. In general, legumes have higher protein content than sesame; as a result germinating legumes could produce more GABA than sesame.

\subsection{Physicochemical composition of germinated legumes and sesame}

Germination process affected the physicochemical composition of germinated grains (Table 1). The protein content of non germinated mung bean and black bean was 0.2457 and $0.2625 \mathrm{~g} \mathrm{~kg}^{-1}$ (dry weight basis), respectively. After soaking and incubation, the protein content increased with incubation time and reached up to 0.2940 and $0.2760 \mathrm{~g} \mathrm{~kg}^{-1}$ dry weight basis at $48 \mathrm{~h}$ in germinated mung bean and black bean, respectively. These results are in agreement with other works where an increase of crude protein content during germination were reported in mung bean (Mubarak, 2005) and tigernut (Chinma et al., 2009). The increasing protein content by germination could be attributed to synthesis of several enzymes and resulted in the production of some non-protein nitrogen containing compounds (Moongngarm \& Saetung, 2010). On the other hand the protein content in soybean and sesame increased only slightly during germination. These findings are similar to that of Donangelo et al. (1995) observing that $48 \mathrm{~h}$ germination of soybean led to only a small increase in crude protein, while crude protein remained almost unchanged throughout the germination period in sesame (Hahma et al., 2009). The recent study of Shen et al. (2015) found that most of free amino acids significantly increased in brown rice after germination in anaerobic condition for $10 \mathrm{~h}$, whereas the serine and threonine contents remained unchanged, the content of aspartic acid and glutamic acid decreased. These changes can be explained by accumulation of free amino acids from the assimilation of the nitrate stored during the early stage of anaerobic germination of seeds and later probably come from the breakdown of storage protein followed by the translocation of amino acids.

Concerning fat content in germinated grains, incubation periods did not have any effect on it in germinated mung bean, soybean and black bean. This appears to be similar to that of found by Moongngarm \& Saetung (2010) in brown rice. However in germinated sesame, fat content decreased during germination period (Table 1). This is could be attributed to the use of fat as an energy source to start germination as described by Hahma et al. (2009). Fat could be hydrolysed during germination and used to produce the necessary energy for the biochemical and physicochemical modifications that occur throughout the germination.

The incubation period affected the ash content in all germinated grains. It was found that ash content significantly decreased during germination. These results are in agreement with the decreasing ash content during germination found in mung bean (Mubarak, 2005), legumes such as green gram, cow pea, lentil and chick pea (Ghavidel \& Prakash, 2007). It was suggested that solid matter leaching from the seeds during the soaking process could be the reason for significant reduction of minerals in germination.

Carbohydrate amount in legumes and sesame were also estimated. Considering the non germinated grains, mung bean and black bean had higher carbohydrate content than soybean and sesame. As incubation periods lengthened, decreasing amount of carbohydrates was found in germinated mung bean. This is possibly due to their use as an energy source to fuel germination. During germination of grains and legumes, biochemical activities produce simple molecules such as sugars, amino acids and minerals from more complex chemical constituents for the formation and growth of seedling (Saman et al., 2008). In addition, increasing a-amylase activity during germination could also be a possible explanation for the carbohydrate loss. On the other hand, there was no significant change in carbohydrate content of germinated soybean, black bean and sesame. These findings are similar to that of reported in germinated rough rice and brown rice by Moongngarm \& Saetung (2010). 
Table 1. Effect of incubation periods on the physicochemical composition of germinated grains ( $\mathrm{g} \mathrm{kg}^{-1} \mathrm{dry}^{\text {weight basis). }}$

\begin{tabular}{|c|c|c|c|c|c|}
\hline Samples & Incubation periods (h) & Protein & Fat & Ash & Carbohydrate \\
\hline \multirow{7}{*}{ Mung bean } & NG & $(0.246 \pm 0.001)^{c}$ & $(0.017 \pm 0.002)^{\mathrm{a}}$ & $(0.036 \pm 0.001)^{\mathrm{a}}$ & $(0.699 \pm 0.005)^{\mathrm{a}}$ \\
\hline & 0 & $(0.243 \pm 0.005)^{c}$ & $(0.017 \pm 0.003)^{\mathrm{a}}$ & $(0.032 \pm 0.001)^{\mathrm{b}}$ & $(0.707 \pm 0.005)^{\mathrm{a}}$ \\
\hline & 6 & $(0.252 \pm 0.002)^{c}$ & $(0.017 \pm 0.003)^{\mathrm{a}}$ & $(0.032 \pm 0.001)^{\mathrm{b}}$ & $(0.698 \pm 0.005)^{\mathrm{a}, \mathrm{b}}$ \\
\hline & 12 & $(0.263 \pm 0.008)^{b}$ & $(0.016 \pm 0.003)^{\mathrm{a}}$ & $(0.032 \pm 0.001)^{\mathrm{b}}$ & $(0.687 \pm 0.005)^{\mathrm{b}, \mathrm{c}}$ \\
\hline & 24 & $(0.268 \pm 0.011)^{\mathrm{b}}$ & $(0.016 \pm 0.002)^{\mathrm{a}}$ & $(0.032 \pm 0.001)^{\mathrm{b}}$ & $(0.681 \pm 0.012)^{c}$ \\
\hline & 36 & $(0.264 \pm 0.002)^{b}$ & $(0.017 \pm 0.002)^{\mathrm{a}}$ & $(0.032 \pm 0.001)^{\mathrm{b}}$ & $(0.686 \pm 0.001)^{c}$ \\
\hline & 48 & $(0.294 \pm 0.005)^{\mathrm{a}}$ & $(0.017 \pm 0.003)^{\mathrm{a}}$ & $(0.032 \pm 0.001)^{\mathrm{b}}$ & $(0.656 \pm 0.035)^{\mathrm{d}}$ \\
\hline \multirow{7}{*}{ Soybean } & NG & $(0.445 \pm 0.011)^{\mathrm{a}}$ & $(0.212 \pm 0.015)^{a}$ & $(0.051 \pm 0.001)^{\mathrm{a}}$ & $(0.292 \pm 0.012)^{\mathrm{a}}$ \\
\hline & 0 & $(0.446 \pm 0.002)^{\mathrm{a}}$ & $(0.204 \pm 0.004)^{\mathrm{a}}$ & $(0.041 \pm 0.001)^{c}$ & $(0.308 \pm 0.006)^{\mathrm{a}}$ \\
\hline & 6 & $(0.450 \pm 0.011)^{\mathrm{a}}$ & $(0.208 \pm 0.012)^{\mathrm{a}}$ & $(0.043 \pm 0.001)^{\mathrm{b}}$ & $(0.318 \pm 0.022)^{\mathrm{a}}$ \\
\hline & 12 & $(0.443 \pm 0.014)^{\mathrm{a}}$ & $(0.206 \pm 0.005)^{\mathrm{a}}$ & $(0.040 \pm 0.001)^{\mathrm{d}}$ & $(0.312 \pm 0.014)^{\mathrm{a}}$ \\
\hline & 24 & $(0.445 \pm 0.012)^{\mathrm{a}}$ & $(0.205 \pm 0.017)^{\mathrm{a}}$ & $(0.040 \pm 0.001)^{\mathrm{d}}$ & $(0.310 \pm 0.004)^{\mathrm{a}}$ \\
\hline & 36 & $(0.448 \pm 0.011)^{\mathrm{a}}$ & $(0.210 \pm 0.017)^{\mathrm{a}}$ & $(0.035 \pm 0.001)^{\mathrm{e}}$ & $(0.307 \pm 0.007)^{\mathrm{a}}$ \\
\hline & 48 & $(0.449 \pm 0.012)^{\mathrm{a}}$ & $(0.208 \pm 0.010)^{\mathrm{a}}$ & $(0.035 \pm 0.001)^{\mathrm{e}}$ & $(0.308 \pm 0.023)^{\mathrm{a}}$ \\
\hline \multirow{7}{*}{ Black bean } & NG & $(0.263 \pm 0.001)^{b}$ & $(0.017 \pm 0.001)^{\mathrm{a}}$ & $(0.036 \pm 0.001)^{\mathrm{a}}$ & $(0.685 \pm 0.001)^{\mathrm{a}}$ \\
\hline & 0 & $(0.265 \pm 0.001)^{\mathrm{b}}$ & $(0.017 \pm 0.001)^{\mathrm{a}}$ & $(0.035 \pm 0.001)^{\mathrm{a}, \mathrm{b}}$ & $(0.685 \pm 0.011)^{\mathrm{a}}$ \\
\hline & 6 & $(0.272 \pm 0.002)^{\mathrm{a}}$ & $(0.017 \pm 0.001)^{\mathrm{a}}$ & $(0.033 \pm 0.002)^{\mathrm{b}}$ & $(0.678 \pm 0.009)^{\mathrm{a}}$ \\
\hline & 12 & $(0.272 \pm 0.005)^{\mathrm{a}}$ & $(0.015 \pm 0.003)^{\mathrm{a}}$ & $(0.033 \pm 0.001)^{\mathrm{a}, \mathrm{b}}$ & $(0.680 \pm 0.013)^{\mathrm{a}}$ \\
\hline & 24 & $(0.272 \pm 0.002)^{\mathrm{a}}$ & $(0.015 \pm 0.001)^{\mathrm{a}}$ & $(0.033 \pm 0.001)^{\mathrm{a}, \mathrm{b}}$ & $(0.680 \pm 0.003)^{\mathrm{a}}$ \\
\hline & 36 & $(0.272 \pm 0.008)^{\mathrm{a}}$ & $(0.014 \pm 0.001)^{\mathrm{a}}$ & $(0.034 \pm 0.002)^{\mathrm{a}, \mathrm{b}}$ & $(0.679 \pm 0.008)^{\mathrm{a}}$ \\
\hline & 48 & $(0.276 \pm 0.002)^{\mathrm{a}}$ & $(0.015 \pm 0.001)^{\mathrm{a}}$ & $(0.034 \pm 0.002)^{\mathrm{a}, \mathrm{b}}$ & $(0.676 \pm 0.009)^{\mathrm{a}}$ \\
\hline \multirow{7}{*}{ Sesame } & NG & $(0.215 \pm 0.003)^{\mathrm{a}}$ & $(0.574 \pm 0.027)^{\mathrm{a}}$ & $(0.051 \pm 0.001)^{\mathrm{a}}$ & $(0.160 \pm 0.029)^{\mathrm{a}}$ \\
\hline & 0 & $(0.220 \pm 0.005)^{\mathrm{a}}$ & $(0.569 \pm 0.021)^{\mathrm{a}}$ & $(0.050 \pm 0.001)^{\mathrm{a}, \mathrm{b}}$ & $(0.162 \pm 0.026)^{\mathrm{a}}$ \\
\hline & 6 & $(0.219 \pm 0.280)^{\mathrm{a}}$ & $(0.562 \pm 0.020)^{\mathrm{a}, \mathrm{b}}$ & $(0.048 \pm 0.001)^{\mathrm{b}}$ & $(0.171 \pm 0.021)^{\mathrm{a}}$ \\
\hline & 12 & $(0.223 \pm 0.008)^{\mathrm{a}}$ & $(0.554 \pm 0.010)^{\mathrm{a}, \mathrm{b}}$ & $(0.048 \pm 0.001)^{\mathrm{b}}$ & $(0.176 \pm 0.011)^{\mathrm{a}}$ \\
\hline & 24 & $(0.221 \pm 0.006)^{\mathrm{a}}$ & $(0.557 \pm 0.017)^{\mathrm{a}, \mathrm{b}}$ & $(0.048 \pm 0.001)^{\mathrm{b}}$ & $(0.175 \pm 0.020)^{\mathrm{a}}$ \\
\hline & 36 & $(0.220 \pm 0.002)^{\mathrm{a}}$ & $(0.546 \pm 0.017)^{\mathrm{a}, \mathrm{b}}$ & $(0.048 \pm 0.002)^{\mathrm{b}}$ & $(0.186 \pm 0.015)^{\mathrm{a}}$ \\
\hline & 48 & $(0.224 \pm 0.005)^{\mathrm{a}}$ & $(0.533 \pm 0.012)^{\mathrm{b}}$ & $(0.047 \pm 0.002)^{\mathrm{b}}$ & $(0.195 \pm 0.016)^{\mathrm{a}}$ \\
\hline
\end{tabular}

NG denotes non germinated grains; Data expressed as means \pm SD of three independent experiments; ${ }^{\text {ae }}$ Means in the same column of each grain type with different letters are significantly different $(p<0.05)$.

\subsection{Dietary fibers in germinated legumes and sesame}

Dietary fibers play an important role in prevention of cardiovascular diseases, cancer, diabetes and others (Girish et al., 2012). Each fraction of insoluble dietary fiber (IDF) and soluble dietary fiber (SDF) has different physiological effect. The IDF relates to both water absorption and intestinal regulation, whereas SDF associates with cholesterol in blood and diminishes its intestinal absorption. Mostly, total dietary fiber (TDF) content in the tested grains increased during germination (Table 2). The IDF, SDF and TDF contents in non germinated mung bean were $0.1464,0.0066$ and $0.1530 \mathrm{~g} \mathrm{~kg}^{-1}$ dry weight basis, respectively, indicating that the IDF is the main dietary fiber fraction in mung bean. The IDF content increased up to 0.1640 , $0.1874,0.1990$ and $0.2057 \mathrm{~g} \mathrm{~kg}^{-1}$ dry weight basis after soaking and incubation for $6 \mathrm{~h}, 12 \mathrm{~h}$ and $24 \mathrm{~h}$, respectively. Afterwards the IDF content slightly decreased to 0.1965 and $0.1896 \mathrm{~g} \mathrm{~kg}^{-1}$ dry weight basis at $36 \mathrm{~h}$ and $48 \mathrm{~h}$, respectively. Besides, SDF and TDF amounts also increased during germination. The SDF content in germinated mung bean reached up to $0.0179 \mathrm{~g} \mathrm{~kg}^{-1}$ dry weight basis at $48 \mathrm{~h}$. While the TDF content increased from 0.1783 to 0.2036 and $0.2212 \mathrm{~g} \mathrm{~kg}^{-1}$ dry weight basis after 6 and $24 \mathrm{~h}$, respectively.

The SDF content in germinated soybean changed only slightly during germination. However, the amount of IDF and TDF in germinated soybean was significantly increased. The highest IDF ( $0.2073 \mathrm{~g} \mathrm{~kg}^{-1}$ dry weight basis) and TDF $\left(0.2467 \mathrm{~g} \mathrm{~kg}^{-1} \mathrm{dry}\right.$ weight basis) contents in germinated soybean were obtained after 12 hours of incubation. The SDF content in black bean increased gradually during germination up until $36 \mathrm{~h}$, whereas IDF and TDF were slightly changed. The IDF, SDF, and TDF contents of germinated sesame were also increased during germination period. The results suggested that the germination process increased the dietary fibers (IDF, SDF and TDF) content of germinated grains. Our findings also reveal that the IDF contents were higher than the SDF contents in germinated legumes and sesame. Thus, the incorporation of these germinated legumes' fibers in food could be useful particularly in the development of foods with improved digestibility, as suggested by Martin-Cabrejas et al. (2008). Aguerre et al. (2015) also reported that the combination of germination and ensiling resulted in changes in the chemical composition and improved the digestibility of sorghum grains. 
Table 2. Insoluble, soluble, and total dietary fiber content in germinated grains ( $\mathrm{g} \mathrm{kg}^{-1} \mathrm{dry}$ weight basis).

\begin{tabular}{|c|c|c|c|c|}
\hline Samples & Incubation periods $(\mathrm{h})$ & IDF & SDF & TDF \\
\hline \multirow{7}{*}{ Mung bean } & NG & $(0.146 \pm 0.007)^{\mathrm{d}}$ & $(0.007 \pm 0.001)^{\mathrm{d}}$ & $(0.153 \pm 0.008)^{\mathrm{d}}$ \\
\hline & 0 & $(0.164 \pm 0.009)^{c}$ & $(0.014 \pm 0.001)^{c}$ & $(0.178 \pm 0.009)^{c}$ \\
\hline & 6 & $(0.187 \pm 0.010)^{\mathrm{b}}$ & $(0.016 \pm 0.002)^{a, b, c}$ & $(0.204 \pm 0.012)^{\mathrm{b}}$ \\
\hline & 12 & $(0.199 \pm 0.90)^{\mathrm{a}, \mathrm{b}}$ & $(0.015 \pm 0.001)^{\mathrm{b}, \mathrm{c}}$ & $(0.214 \pm 0.010)^{\mathrm{a}, \mathrm{b}}$ \\
\hline & 24 & $(0.206 \pm 0.008)^{\mathrm{a}}$ & $(0.016 \pm 0.001)^{\mathrm{b}, \mathrm{c}}$ & $(0.221 \pm 0.008)^{\mathrm{a}}$ \\
\hline & 36 & $(0.197 \pm 0.007)^{\mathrm{a}, \mathrm{b}}$ & $(0.017 \pm 0.001)^{\mathrm{a}, \mathrm{b}}$ & $(0.213 \pm 0.006)^{\mathrm{a}, \mathrm{b}}$ \\
\hline & 48 & $(0.190 \pm 0.006)^{\mathrm{b}}$ & $(0.018 \pm 0.002)^{\mathrm{a}}$ & $(0.208 \pm 0.006)^{\mathrm{a}, \mathrm{b}}$ \\
\hline \multirow{7}{*}{ Soybean } & NG & $(0.196 \pm 0.003)^{b}$ & $(0.038 \pm 0.001)^{\mathrm{a}}$ & $(0.234 \pm 0.004)^{\mathrm{a}, \mathrm{b}}$ \\
\hline & 0 & $(0.199 \pm 0.005)^{\mathrm{a}, \mathrm{b}}$ & $(0.038 \pm 0.001)^{\mathrm{a}}$ & $(0.237 \pm 0.006)^{\mathrm{a}, \mathrm{b}}$ \\
\hline & 6 & $(0.201 \pm 0.005)^{\mathrm{a}, \mathrm{b}}$ & $(0.039 \pm 0.002)^{\mathrm{a}}$ & $(0.240 \pm 0.007)^{\mathrm{a}, \mathrm{b}}$ \\
\hline & 12 & $(0.207 \pm 0.005)^{\mathrm{a}}$ & $(0.040 \pm 0.002)^{\mathrm{a}}$ & $(0.247 \pm 0.007)^{\mathrm{a}}$ \\
\hline & 24 & $(0.194 \pm 0.010)^{\mathrm{b}}$ & $(0.038 \pm 0.001)^{\mathrm{a}}$ & $(0.232 \pm 0.011)^{\mathrm{b}}$ \\
\hline & 36 & $(0.197 \pm 0.005)^{\mathrm{a}, \mathrm{b}}$ & $(0.040 \pm 0.002)^{\mathrm{a}}$ & $(0.237 \pm 0.004)^{\mathrm{a}, \mathrm{b}}$ \\
\hline & 48 & $(0.199 \pm 0.003)^{\mathrm{a}, \mathrm{b}}$ & $(0.040 \pm 0.001)^{\mathrm{a}}$ & $(0.239 \pm 0.004)^{\mathrm{a}, \mathrm{b}}$ \\
\hline \multirow{7}{*}{ Black bean } & NG & $(0.198 \pm 0.001)^{c}$ & $(0.005 \pm 0.002)^{d}$ & $(0.203 \pm 0.003)^{\mathrm{d}}$ \\
\hline & 0 & $(0.200 \pm 0.002)^{c}$ & $(0.007 \pm 0.002)^{c}$ & $(0.208 \pm 0.003)^{c, \mathrm{~d}}$ \\
\hline & 6 & $(0.199 \pm 0.007)^{c}$ & $(0.011 \pm 0.001)^{\mathrm{b}}$ & $(0.210 \pm 0.006)^{c}$ \\
\hline & 12 & $(0.120 \pm 0.004)^{c}$ & $(0.011 \pm 0.002)^{\mathrm{b}}$ & $(0.210 \pm 0.005)^{c}$ \\
\hline & 24 & $(0.215 \pm 0.002)^{\mathrm{b}}$ & $(0.016 \pm 0.001)^{\mathrm{a}}$ & $(0.230 \pm 0.002)^{\mathrm{b}}$ \\
\hline & 36 & $(0.224 \pm 0.002)^{\mathrm{a}}$ & $(0.017 \pm 0.001)^{\mathrm{a}}$ & $(0.240 \pm 0.002)^{\mathrm{a}}$ \\
\hline & 48 & $(0.225 \pm 0.003)^{\mathrm{a}}$ & $(0.017 \pm 0.001)^{\mathrm{a}}$ & $(0.242 \pm 0.003)^{\mathrm{a}}$ \\
\hline \multirow{7}{*}{ Sesame } & NG & $(0.135 \pm 0.004)^{\mathrm{d}}$ & $(0.029 \pm 0.004)^{\mathrm{d}}$ & $(0.164 \pm 0.008)^{c}$ \\
\hline & 0 & $(0.137 \pm 0.002)^{\mathrm{d}}$ & $(0.033 \pm 0.002)^{c}$ & $(0.170 \pm 0.004)^{c}$ \\
\hline & 6 & $(0.138 \pm 0.003)^{\mathrm{d}}$ & $(0.031 \pm 0.001)^{\mathrm{c,d}}$ & $(0.170 \pm 0.004)^{c}$ \\
\hline & 12 & $(0.147 \pm 0.001)^{c}$ & $(0.035 \pm 0.002)^{c}$ & $(0.181 \pm 0.003)^{\mathrm{b}}$ \\
\hline & 24 & $(0.152 \pm 0.001)^{\mathrm{b}}$ & $(0.035 \pm 0.001)^{c}$ & $(0.187 \pm 0.003)^{\mathrm{b}}$ \\
\hline & 36 & $(0.161 \pm 0.002)^{\mathrm{a}}$ & $(0.048 \pm 0.001)^{\mathrm{b}}$ & $(0.209 \pm 0.003)^{\mathrm{a}}$ \\
\hline & 48 & $(0.162 \pm 0.001)^{\mathrm{a}}$ & $(0.053 \pm 0.001)^{\mathrm{a}}$ & $(0.215 \pm 0.002)^{\mathrm{a}}$ \\
\hline
\end{tabular}

NG denotes non germinated grains; Data expressed as means \pm SD of three independent experiments; ${ }^{\text {a-d }}$ Means in the same column of each grain type with different letters are significantly different $(p<0.05)$.

\subsection{DPPH radical scavenging activity and total phenolics in germinated legumes and sesame}

The DPPH radical is considered to be a model of a stable lipophilic radical. Antioxidants react with DPPH radical, reducing the number of DPPH molecules equal to the number of their available hydroxyl groups. Therefore, the absorption at $517 \mathrm{~nm}$ is proportional to the amount of residual DPPH (Xu et al., 2005). Also, phenolic compounds are known to exhibit free-radical scavenging (antioxidant) activity, which is determined by their reactivity as hydrogen or electron donors (Fernandez-Orozco et al., 2008). DPPH activity and total phenolics of non germinated and germinated grains are shown in Figure 2. In mung bean, the DPPH activity slightly decreased and total phenolics content showed no significant change during germination (Figure $2 \mathrm{a}$ ). Contradictory, in soybean the DPPH activity increased but total phenolics changed only marginally during germination (Figure 2b). In black bean the trend of DPPH activity and total phenolics was similar to that of germinated mung bean (Figure 2c). Interestingly, DPPH activity of sesame decreased dramatically after soaking and then slightly increased again as the germination progressed. However, there was no significant change in the total phenolics content found in germinated sesame (Figure $2 \mathrm{~d}$ ).
The results suggested that the germination process only slightly affected the total phenolics content of germinated grains in this study. Although the DPPH activity in germinated soybean and sesame increased, it decreased in germinated mung bean and black bean. However, the study of Shen et al. (2015) showed that in germinated brown rice using anaerobic treatment phenolics content and DPPH activity were found to be increased throughout germination period. It was explained by the anaerobic treatment, as one of the stress factors, may activate phenylalanine ammonia lyase that responsible for the synthesis of phenolics and resulted in an increase of total phenolics during germination. Wang et al. (2015) also found that total phenolics content was increased inconsistently in germinated soybean of the three cultivars. This indicates that genetics can be an important factor for phenolic compound synthesis during germination.

In this study, the trend of total phenolics content cannot absolutely predict the activity of DPPH scavenging in germinated grains. As in a previous research, Randhir \& Shetty (2007) suggested that the antioxidant attribute of mung bean extract may depend on the qualitative characteristics of phenolic profile and not just on the total amount of phenolics. However, changes of antioxidant activities during germination in grains have not been fully understood yet. 


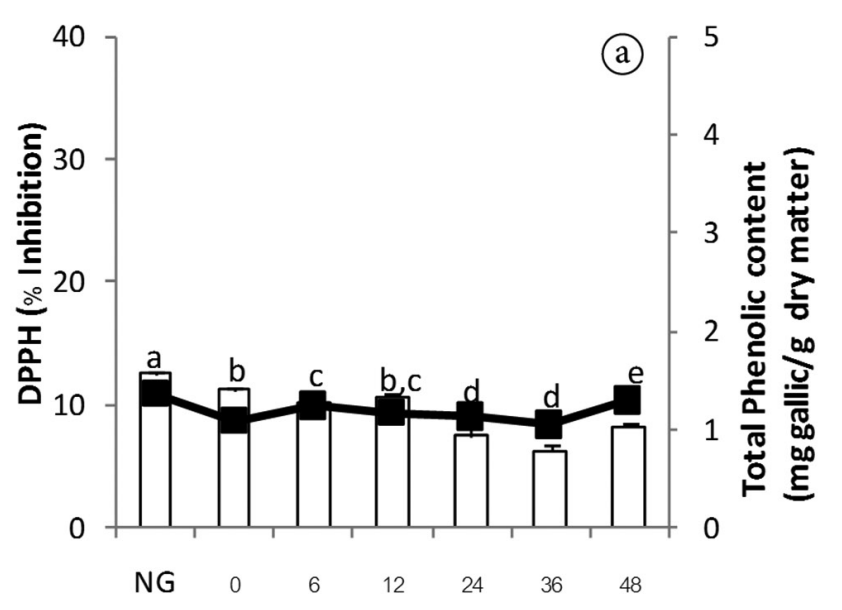

Incubation time (h)
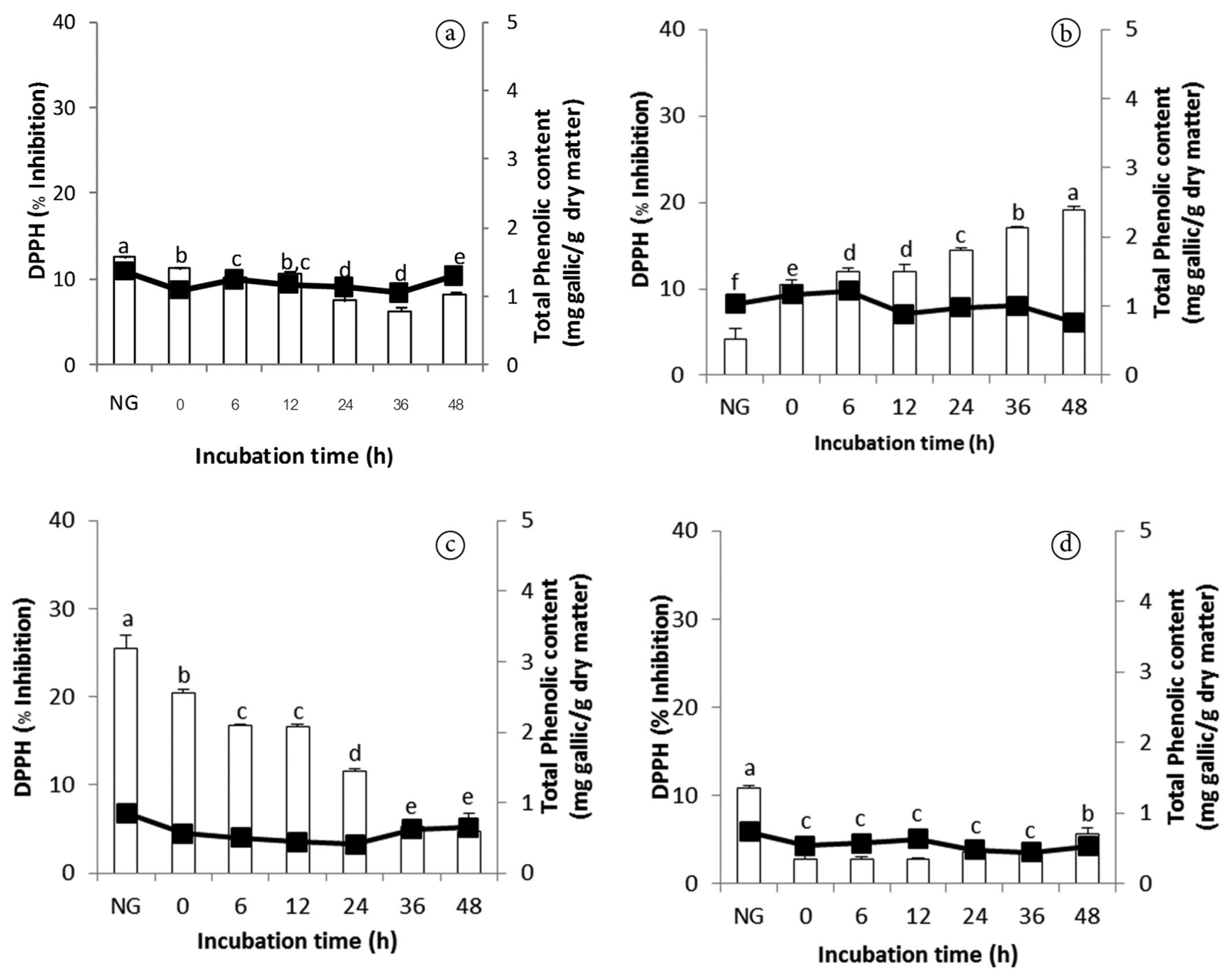

Figure 2. DPPH scavenging activity (bar $\square$ ) and total phenolics (line - - ) of germinated grains for different incubation periods, NG denotes non germinated grains. (a) Germinated mung bean. (b) Germinated soybean. (c) Germinated black bean. (d) Germinated sesame. Data reported are the mean \pm SD of triplicate determinations. ${ }^{a-e}$ Means of each grain type with different letters are significantly different $(p<0.05)$.

\subsection{The effect of cooking process on GABA content in germinated legumes and sesame}

The cooking processes chosen in this study were mainly based on Eastern traditional and household cooking methods for legumes and sesame. The condition of each cooking method was established for laboratory scale in order to obtain cooked legumes and sesame. The GABA contents of non-processed and processed germinated grains are presented in Table 3. GABA contents were significantly $(p<0.05)$ decreased by all cooking methods. In germinated mung bean, all the cooking processes decreased the concentrations of GABA. The remaining amounts of GABA were $0.0634,0.1778,0.2184$ and $0.1834 \mathrm{~g} \mathrm{~kg}^{-1}$ dry matter after the boiling, steaming, microwave cooking and open pan roasting process, respectively. This suggests that microwave cooking process in germinated mung bean is the least harmful on GABA. In case of germinated soybean, it appears that steaming allowed the highest GABA content to remain. Similar result was obtained in germinated black bean, where steaming affected only about $25 \%$ of the GABA content. In germinated sesame, the GABA content was $0.0716,0.0730,0.1584$ and $0.0928 \mathrm{~g} \mathrm{~kg}^{-1}$ dry matter after boiling, steaming, microwave cooking and open pan roasting process, respectively. Although microwave cooking retained the highest GABA content in germinated sesame, the second least harmful was open pan roasting which generated a roasted odor, a specific characteristic of roasted sesame and that may be important, as roasting is common process for sesame in Asia.

Our results suggest that microwave cooking is recommended for germinated soybean and black bean preparation. Also, both steaming and microwave cooking process generated the soft texture of grains, which is suitable for semi-moist food such as salad or soup. On the other hand, open pan roasting provided drier texture of grains and roasted odor that are suitable for use as an ingredient in cereal products, particularly in cereal bar. 
Table 3. Effect of some cooking processes on the GABA content ( $\mathrm{g} \mathrm{kg}^{-1}$ dry weight basis) of germinated grains at optimal incubation time.

\begin{tabular}{lcccc}
\hline \multirow{2}{*}{ Cooking Process } & \multicolumn{4}{c}{ GABA content $\left(\mathrm{g} \mathrm{kg}^{-1}\right.$ dry weight basis) } \\
\cline { 2 - 5 } & Germinated mung bean at 24 h & Germinated soy bean at 6 h & Germinated black bean at 6 h & Germinated sesame at 0 h \\
\hline Uncooked & $(0.807 \pm 0.026)^{\mathrm{a}}$ & $(0.498 \pm 0.012)^{\mathrm{a}}$ & $(0.743 \pm 0.010)^{\mathrm{a}}$ & $(0.165 \pm 0.003)^{\mathrm{a}}$ \\
Boiling & $(0.063 \pm 0.021)^{\mathrm{d}}$ & $(0.204 \pm 0.006)^{\mathrm{d}}$ & $(0.310 \pm 0.012)^{\mathrm{e}}$ & $(0.072 \pm 0.005)^{\mathrm{d}}$ \\
Steaming & $(0.178 \pm 0.005)^{\mathrm{c}}$ & $(0.407 \pm 0.020)^{\mathrm{b}}$ & $(0.558 \pm 0.024)^{\mathrm{b}}$ & $(0.073 \pm 0.001)^{\mathrm{d}}$ \\
Microwave cooking & $(0.218 \pm 0.007)^{\mathrm{b}}$ & $(0.191 \pm 0.005)^{\mathrm{d}}$ & $(0.455 \pm 0.021)^{\mathrm{c}}$ & $(0.158 \pm 0.001)^{\mathrm{b}}$ \\
Open pan roasting & $(0.183 \pm 0.014)^{\mathrm{c}}$ & $(0.306 \pm 0.012)^{\mathrm{c}}$ & $(0.386 \pm 0.020)^{\mathrm{d}}$ & $(0.093 \pm 0.005)^{\mathrm{c}}$ \\
\hline
\end{tabular}

Data expressed as means \pm SD of three independent experiments; ${ }^{\mathrm{a}-\mathrm{e}}$ Means in the same column with different letters are significantly different $(p<0.05)$.

\section{Conclusions}

In conclusion, during germination process, there was a significant increase in GABA amounts in mung bean, black bean, soy bean and sesame. Germinated mung bean provided the highest content of GABA at $24 \mathrm{~h}\left(0.8068 \mathrm{~g} \mathrm{~kg}^{-1}\right.$ dry weight). In general, total crude protein, fat and carbohydrate contents were different in each kind of seed and sampling time. It was clearly found that the concentration of crude protein in germinated mung bean and black bean increased during germination. Ash content was found decreased in all germinated grains. Mostly, total dietary fiber content increased during germination. Our important finding was that germinated legumes and sesame especially mung bean could be potential nutritional sources of GABA and dietary fibers. Additionally, all the cooking processes were found to decrease GABA contents in germinated grains. However, steaming was found to be the least destructive for GABA contents in black bean and soybean, whereas microwave cooking allowed the smallest loss of GABA contents in mung bean and sesame.

\section{Acknowledgements}

This research has been granted by the Center of Excellence on Agricultural Biotechnology, Science and Technology Postgraduate Education and Research Development Office, Office of Higher Education Commission, Ministry of Education (AG-BIO/PERDO-CHE), Thailand.

\section{References}

Aguerre, M., Cajarville, C., \& Repetto, J. L. (2015). Impact of water addition, germination, ensiling and their association on sorghum grain nutritive value. Animal Feed Science and Technology, 205, 7581. http://dx.doi.org/10.1016/j.anifeedsci.2015.04.016.

Alajaji, S. A., \& El-Adawy, T. A. (2006). Nutritional composition of chickpea (Cicer arietinum L.) as affected by microwave cooking and other traditional cooking methods. Journal of Food Composition and Analysis, 19(8), 806-812. http://dx.doi.org/10.1016/j.jfca.2006.03.015.

Association of Official Analytical Chemists - AOAC. (1990a). Official Methods of Analysis of AOAC International (15th ed., Method 923.23). Arlington: AOAC.

Association of Official Analytical Chemists - AOAC. (1990b). Official Methods of Analysis of AOAC International (15th ed., Method 979.09). Arlington: AOAC.

Association of Official Analytical Chemists - AOAC. (2000). Official Methods of Analysis of AOAC International (17th ed., Method 920.39). Gaithersburg: AOAC.
Bau, H. M., Villanme, C., Nicolos, J. P., \& Mejean, L. (1997). Effect of germination on chemical composition, biochemical constitutes and antinutritional factors of soy bean (Glycine max) seeds. Journal of the Science of Food and Agriculture, 73(1), 1-9. http://dx.doi.org/10.1002/ (SICI)1097-0010(199701)73:1<1::AID-JSFA694>3.0.CO;2-B.

Butsat, S., \& Siriamornpun, S. (2010). Antioxidant capacities and phenolic compounds of the husk, bran and endosperm of Thai rice. Food Chemistry, 119(2), 606-613. http://dx.doi.org/10.1016/j. foodchem.2009.07.001.

Castrorubio, A., Garcia, M., \& Marina, M. (2006). Rapid separation of soybean and cereal (wheat, corn, and rice) proteins in complex mixtures: Application to the selective determination of the soybean protein content in commercial cereal-based products. Analytica Chimica Acta, 558(1-2), 28-34. http://dx.doi.org/10.1016/j.aca.2005.10.076.

Chinma, C. E., Adewuyi, O., \& Abu, J. O. (2009). Effect of germination on the chemical, functional and pasting properties of flour from brown and yellow varieties of tigernut (Cyperus esculentus). Food Research International, 42(8), 1004-1009. http://dx.doi.org/10.1016/j. foodres.2009.04.024.

Chung, H. J., Jang, S. H., Cho, H. Y., \& Lim, S. T. (2009). Effects of steeping and anaerobic treatment on GABA ( $\gamma$-aminobutyric acid) content in germinated waxy hull-less barley. LWT-Food Science and Technology, 42(10), 1712-1716. http://dx.doi.org/10.1016/j. lwt.2009.04.007.

Donangelo, C. M., Trugo, O. L. C., Trugo, N. M. F., \& Eggumb, B. (1995). Effect of germination of legume seeds on chemical composition and on protein and energy utilization in rats. Food Chemistry, 53(1), 23-27. http://dx.doi.org/10.1016/0308-8146(95)95781-Z.

Fernandez-Orozco, R., Frias, J., Zielinski, H., Piskula, M. K., Kozlowska, H., \& Vidal-Valverde, C. (2008). Kinetic study of the antioxidant compounds and antioxidant capacity during germination of Vigna radiata cv. emmerald, Glycine max cv. jutro and Glycine max cv. merit. Food Chemistry, 111(3), 622-630. http://dx.doi.org/10.1016/j. foodchem.2008.04.028.

Ghavidel, R. A., \& Prakash, J. (2007). The impact of germination and dehulling on nutrients, antinutrients, in vitro iron and calcium bioavailability and in vitro starch and protein digestibility of some legume seeds. LWT-Food Science and Technology, 40(7), 1292-1299. http://dx.doi.org/10.1016/j.lwt.2006.08.002.

Girish, T. K., Pratape, V. M., \& Prasada Rao, U. J. S. (2012). Nutrient distribution, phenolic acid composition, antioxidant and alphaglucosidase inhibitory potentials of black gram (Vigna mungo L.) and its milled by-products. Food Research International, 46(1), 370-377. http://dx.doi.org/10.1016/j.foodres.2011.12.026.

Hahma, T. S., Park, S. J., \& Martin, L. Y. (2009). Effects of germination on chemical composition and functional properties of sesame (Sesamun indicum L,) seeds. Bioresource Technology, 100, 1642-1647. http:// dx.doi.org/10.1016/j.biortech.2008.09.034. 
Kim, M. Y., Lee, S. H., Jang, G. Y., Park, H. J., Li, M., Kim, S., Lee, Y. R., Noh, Y. H., Lee, J., \& Jeong, H. S. (2015). Effects of high hydrostatic pressure treatment on the enhancement of functional components of germinated rough rice (Oryza sativa L.). Food Chemistry, 166, 86-92. http://dx.doi.org/10.1016/j.foodchem.2014.05.150. PMid:25053032.

Komatsuzaki, N., Tsukahara, K., Toyoshima, H., Suzuki, T., Shimizu, N., \& Kimura, T. (2007). Effect of soaking and gaseous treatment on GABA content in germinated brown rice. Journal of Food Engineering, 78(2), 556-560. http://dx.doi.org/10.1016/j.jfoodeng.2005.10.036.

Martin-Cabrejas, M., Diaz, M., Aguilera, Y., Benitez, V., Molla, E., \& Esteban, R. (2008). Influence of germination on the soluble carbohydrates and dietary fibre fractions in non-conventional legumes. Food Chemistry, 107(3), 1045-1052. http://dx.doi.org/10.1016/j. foodchem.2007.09.020.

Martínez-Villaluenga, C., Kuo, Y.-H., Lambein, F., Frías, J., \& VidalValverde, C. (2006). Kinetics of free protein amino acids, free non-protein amino acids and trigonelline in soybean (Glycine max L.) and lupin (Lupinus angustifolius L.) sprouts. European Food Research and Technology, 224(2), 177-186. http://dx.doi.org/10.1007/ s00217-006-0300-6.

Matsuyama, A., Yoshimura, K., Shimizu, C., Murano, Y., Takeuchi, H., \& Ishimoto, M. (2009). Characterization of glutamate decarboxylase mediating $\gamma$-amino butyric acid increase in the early germination stage of soybean (Glycine max [L.] Merr.). Journal of Bioscience and Bioengineering, 107(5), 538-543. http://dx.doi.org/10.1016/j. jbiosc.2009.01.012. PMid:19393555.

Moongngarm, A., \& Saetung, N. (2010). Comparison of chemical compositions and bioactive compounds of germinated rough rice and brown rice. Food Chemistry, 122(3), 782-788. http://dx.doi. org/10.1016/j.foodchem.2010.03.053.

Mubarak, A. E. (2005). Nutritional composition and antinutritional factors of mung bean seeds (Phaseolus aureus) as affected by some home traditional processes. Food Chemistry, 89(4), 489-495. http:// dx.doi.org/10.1016/j.foodchem.2004.01.007.

Oh, C. H., \& Oh, S. H. (2004). Effect of germinated brown rice extracts with enhanced levels of GABA on cancer cell proliferation and apoptosis. Journal of Medicinal Food, 7(1), 19-23. http://dx.doi. org/10.1089/109662004322984653. PMid:15117548.

Oh, S. H., \& Choi, W. G. (2001). Changes in the levels of $\gamma$-aminobutyric acid and glutamate decarboxylase in developing soybean seedlings. Journal of Plant Research, 114(3), 309-313. http://dx.doi.org/10.1007/ PL00013992.

Randhir, R., \& Shetty, K. (2007). Mung beans processed by solid-state bioconversion improves phenolic content and functionality relevant for diabetes and ulcer management. Innovative Food Science \& Emerging Technologies, 8(2), 197-204. http://dx.doi.org/10.1016/j. ifset.2006.10.003.

Rangkadilok, N., Pholphana, N., Mahidol, C., Wongyai, W., Saengsooksree, K., Nookabkaew, S., \& Satayavivad, J. (2010). Variation of sesamin, sesamolin and tocopherols in sesame (Sesamum indicum L.) seeds and oil products in Thailand. Food Chemistry, 122(3), 724-730. http://dx.doi.org/10.1016/j.foodchem.2010.03.044.
Saman, P., Vázquez, J. A., \& Pandiella, S. S. (2008). Controlled germination to enhance the functional properties of rice. Process Biochemistry, 43(12), 1377-1382. http://dx.doi.org/10.1016/j.procbio.2008.08.007.

Shen, S., Wang, Y., Li, M., Xu, F., Chai, L., \& Bao, J. (2015). The effect of anaerobic treatment on polyphenols, antioxidant properties, tocols and free amino acids in white, red, and black germinated rice (Oryza sativa L.). Journal of Functional Foods, 19, 641-648. http://dx.doi. org/10.1016/j.jff.2015.09.057.

Siddhuraju, P., Osoniyi, O., Makkar, H. P. S., \& Becker, K. (2002). Effect of soaking and ionising radiation on various antinutritional factors of seeds from different species of an unconventional legume, Sesbania and a common legume, green gram (Vigna radiata). Food Chemistry, 79(3), 273-281. http://dx.doi.org/10.1016/S0308-8146(02)00140-1.

Sirisoontaralak, P., Na Nakornpanom, N., Koakietdumrongkul, K., \& Panumaswiwath, C. (2015). Development of quick cooking germinated brown rice with convenient preparation and containing health benefits. LWT -. Food Science and Technology, 61, 138-144. http://dx.doi.org/10.1016/j.lwt.2014.11.015.

Srisang, N., Varanyanond, W., Soponronnarit, S., \& Prachayawarakorn, S. (2011). Effects of heating media and operating conditions on drying kinetics and quality of germinated brown rice. Journal of Food Engineering, 107(3-4), 385-392. http://dx.doi.org/10.1016/j. jfoodeng.2011.06.030.

Thuwapanichayanan, R., Yoosabai, U., Jaisut, D., Soponronnarit, S., \& Prachayawarakorn, S. (2015). Enhancement of $\gamma$-aminobutyric acid in germinated paddy by soaking in combination with anaerobic and fluidized bed heat treatment. Food and Bioproducts Processing, 95, 55-62. http://dx.doi.org/10.1016/j.fbp.2015.03.010.

Wang, F., Wang, H., Wang, D., Fang, F., Lai, J., Wu, T., \& Tsao, R. (2015). Isoflavone, $\gamma$-aminobutyric acid contents and antioxidant activities are significantly increased during germination of three Chinese soybean cultivars. Journal of Functional Foods, 14, 596-604. http:// dx.doi.org/10.1016/j.jff.2015.02.016.

Wang, T. H. F., Tsai, Y. S., Lin, M. L., \& Ou, A. S. (2006). Comparison of bioactive components in GABA tea and green tea produced in Taiwan. Food Chemistry, 96(4), 648-653. http://dx.doi.org/10.1016/j. foodchem.2005.02.046.

$\mathrm{Xu}$, J., Chen, S., \& Hu, Q. (2005). Antioxidant activity of brown pigment and extracts from black sesame seed (Sesamum indicum L.). Food Chemistry, 91(1), 79-83. http://dx.doi.org/10.1016/j. foodchem.2004.05.051.

Xu, J. G., \& Hu, Q. P. (2014). Changes in $\gamma$-aminobutyric acid content and related enzyme activities in Jindou 25 soybean (Glycine max L.) seeds during germination. LWT - Food Science and Technology, 55, 341-346. http://dx.doi.org/10.1016/j.lwt.2013.08.008.

Zhang, H., Yao, H., Chen, F., \& Wang, X. (2007). Purification and characterization of glutamate decarboxylase from rice germ. Food Chemistry, 101(4), 1670-1676. http://dx.doi.org/10.1016/j. foodchem.2006.04.027.

Zhang, Q., Xiang, J., Zhang, L., Zhu, X., Evers, J., van der Werf, W., \& Duan, L. (2014). Optimizing soaking and germination conditions to improve gamma-aminobutyric acid content in japonica and indica germinated brown rice. Journal of Functional Foods, 10, 283-291. http://dx.doi.org/10.1016/j.jff.2014.06.009. 